\title{
Nutrient composition of a low-cost infant's diet formulated from five locally available foodstuffs in northern Nigeria
}

\author{
Enoch Banbilbwa JOEL ${ }^{1 *}$, Simon Gabriel MAFULUL ${ }^{1}$, Richard Joseph KUTSHIK ${ }^{1}$, \\ Habibu TIJJANI ${ }^{2}$, Beduna James GONAP ${ }^{3}$, Barde Larry AUTA ${ }^{4}$, Hamira WELYE ${ }^{1,5}$ and \\ Adebayo Abdulateef EKUNDAYO ${ }^{6}$ \\ ${ }^{l}$ Department of Biochemistry, Faculty of Medical Sciences, University of Jos, Nigeria. \\ ${ }^{2}$ Natural Products Research Laboratory, Department of Biochemistry, Faculty of Sciences, Bauchi State \\ University Gadau, Nigeria. \\ ${ }^{3}$ Department of Basic Sciences, Federal School of Medical Laboratory Technology, Jos, Nigeria. \\ ${ }^{4}$ Department of Biochemistry, Faculty of Natural and Applied Sciences, Plateau State University Bokkos, \\ Nigeria. \\ ${ }^{5}$ United Nation Population Fund (UNFPA), Nigeria. \\ ${ }^{6}$ Clinton Health Access Initiative (CHAI), Kano, Kano State, Nigeria. \\ "Corresponding author; E-mail: enjoebest@yahoo.com; Tel: +234 7037996451
}

\begin{abstract}
In Northern Nigeria, malnutrition remains a major public health problem. This is because the predominant population of rural communities who are low income subsistence farmers cannot afford the commercial fortified infant's food. This research was design to formulate and assess the nutrient composition of a cost effective infant's diet from locally/readily available staple foodstuffs. This is aimed at improving the nutritional status of vulnerable infants and young Children in Northern Nigeria. Standard chemical methods were used to determine the nutrients and antinutrients of the formulated diet and the respective values compared to commonly used commercial complementary diet (as indicated by the manufacturer) in Nigerian market. The results showed that the crude protein of formulated diet was $16.29 \mathrm{~g} / 100 \mathrm{~g}$ which is higher than $15 \mathrm{~g} / 100 \mathrm{~g}$ for control (commercial weaning diet). The energy value of the formulated diet $(416.7 \mathrm{kcal} / 100 \mathrm{~g})$ is comparable to that of the commercial diet $(410.0 \mathrm{kcal} / 100 \mathrm{~g})$. The concentrations of zinc $(31.0 \mathrm{mg} / 100 \mathrm{~g})$ and iron $(8.01 \mathrm{mg} / 100 \mathrm{~g})$ in the formulated diet were significantly higher $(\mathrm{p}<0.05)$ than their corresponding values in the commercial diet. All the essential amino acids were present in the formulated diet. It can be concluded that proper selection and combination of local foodstuffs can provide a cheap and nutritionally rich weaning diet.

(C) 2019 International Formulae Group. All rights reserved.
\end{abstract}

Keywords: Complementary diet, malnutrition, nutrition, local foodstuffs, food composition, antinutrient.

\section{INTRODUCTION}

The United Nations World Food Programme (UNWFP) defines malnutrition as "a state in which the physical function of an individual is impaired to the point where he or she can no longer maintain adequate bodily performance process such as growth, pregnancy, lactation, physical work and resisting and recovering from disease" (WFP, 2005; Bain et al., 2013). The World Health Organization Global index for child growth and malnutrition based on a collection of 
surveys worldwide shows that the prevalence of undernutrition as a result stunting, wasting and underweight is high in developing countries but is reducing in other parts of the world except in Africa (UNICEF, 2007). In sub-Saharan Africa especially in Northern Nigeria, malnutrition is still a persistent challenge for young children due to poor complementary feeding practices (Eshun, 2013). This is because the period around the introduction of complementary foods is the period when malnutrition set-in in many infants which contribute immensely to the high level of malnutrition in children less than 5 years of age worldwide (Daelmans and Saadeh, 2003; Victora et al., 2010).

Young infants thrive best when exclusively breastfed for the first 6 months of life and after that, a prompt and proper complementary foods need to be introduced in addition to continued breastfeeding in order to fully meet their nutrient requirements for optimal growth (WHO and UNICEF, 2003; Soekarjo \& Zehner, 2011). Previous studies have shown that proper combination, processing and blending of certain cereals and legumes have the potential to provide nutrients and serve as complementary food for infants (Fernandez et al., 2002; Solomon, 2005). More so, there is need to provide the poor population with access to affordable means to improve the nutritional quality of complementary foods to supplement breast milk after 6 months of age. The common practice in Northern Nigeria is that mothers prepare complementary foods such as plain pap made up of only one cereal leading to prevalence of malnutrition due to deficiency of essential nutrients. Hence there is need to improve the nutritional quality of the complementary food through careful selection and reformation of locally available food stuff. There has been continuous research aimed at tackling malnutrition particularly in infants and young children in developing countries through formulating weaning diets of high protein and energy value from locally cultivated food crops. Fortified commercial complementary foods are unavailable in rural areas and where available are usually expensive beyond the reach of most families in rural areas especially in Nigeria (Ikujenlola, 2014). Furthermore, rather than replacing the local foods or requiring the low income mothers to buy the expensive commercially available fortified weaning/complementary diet correct combination/formulation of their locally cultivated cereals and legumes that are readily available to the family can be a feasible approach to addressing the nutritional requirements of these infants since $90 \%$ of the people living in the northern region of Nigeria rely on crop cultivation as their primary source of livelihood (Soekarjo \& Zehner, 2011). (FAO/WHO/UNICEF, 1971) has emphasized the use of local foods formulation should be guided by the following principles: (i) high nutritional quality to supplement breastfeeding (ii) acceptability (iii) low price (iv) use of local food item (Dewey and Brown, 2003). Therefore, formulation and development of a balanced complementary diet based on locally and readily available foodstuffs which can provide optimal nutrition to the young child has received a lot of attention in many developing countries including Nigeria (Anigo et al., 2010). This study aimed at contributing to addressing the prevalence of malnutrition in children in Kanam LGA, Plateau State, Nigeria a region in Sub-Saharan Africa through formulation and nutrient analyses of a low-cost and high nutritional value complementary food using locally and readily available food crops.

\section{MATERIALS AND METHODS}

\section{Complementary diet formulation}

The cereal grains, guinea corn (Sorghum bicolar), groundnuts (Arachis hypogea), soya beans (Glycine max), tiger nuts (Cyperus esculentus) and date (Phoenix dactylifera $L$ ) used for this work were obtained from Dengi market in Kanam LGA, Plateau State, Nigeria. All the crops were manually washed. The Groundnut and soya bean were partially roasted and separately washed with water and air-dried. The guinea corn, tiger nuts and date palm were separately soaked and washed with boiled water and air dried. Each portion of guinea corn, tiger nut, 
date palm, roasted groundnut and roasted soya bean were separately taken using the ratio 4:2:2:1:1 respectively and mixed thoroughly. The mixture was homogenized using milling/grinding machine and sieved into fine and smooth powder and then stored in airtight containers at room temperature until used and analysis.

\section{Proximate Determination}

Proximate analysis (in triplicates) was carried out on formulated complementary diet. Moisture, ash, crude protein, crude fat and crude fibre were determined by the recommended methods of the Association of Official Analytical Chemists (AOAC, 1990). Total percentage carbohydrate was obtained by summing up the total values of crude protein, crude fat, crude fibre, moisture and ash constituents of the sample and subtracting it from 100 as reported by Onyeike et al. (1995).

\section{Minerals determination}

Portion of the formulated complementary diet was subjected to acid digestion in a solution according to the method of Allen (1974). The concentrations of the tested mineral elements $(\mathrm{Na}, \mathrm{K}, \mathrm{Ca}, \mathrm{Mg}, \mathrm{P}$, $\mathrm{Mn}, \mathrm{Cu}, \mathrm{Fe}$ and $\mathrm{Zn}$ ) were determined using Atomic Absorption Spectrophotometer (AAS650, Double Beam-Shimadzu, Japan). Phosphorus was determined spectrophotometrically by the vanadomolybdate method (AOAC, 1990).

\section{Amino acid determination}

Amino acid profile was then analysed after acid digestion with Technicon Amino Acid Analyzer (TSM-1), Japan using Norleucine as internal standard using the method described by Spackman et al. (Spackman et al., 1958).

\section{Determination of antinutritional factors}

Phytic acid was determined by the method of (Wheeler \& Ferrel, 1971) and tannin was assayed by the vanillin $\mathrm{HCl}$ (Earp et al., 1981). Cyanide content was determined according to the method of Ikediobi et al. (1980).

\section{Statistical analyses}

Results were expressed as mean \pm standard deviation. The difference between formulated diet and commercial diet of each parameter was determined using one-way analysis of variance (ANOVA) with Instat3 graph prism software and statistical significance was claimed at $\mathrm{P}<0.05$.

\section{RESULTS}

\section{Proximate composition of the formulated complementary diet}

The results of analysis of proximate composition of the formulated complementary diet and the control (commercial weaning diet) are presented in Table 1. As could be seen from the table, the results showed that the crude protein of formulated complementary diet was $16.29 \mathrm{~g} / 100 \mathrm{~g}$ which was higher than $15 \mathrm{~g} / 100 \mathrm{~g}$ of the control (commercial weaning diet). Similarly, the levels of fibre $(2.4 \mathrm{~g} / 100 \mathrm{~g})$, fat $(11.3 \mathrm{~g} / 100 \mathrm{~g})$ and moisture $(5.75 \mathrm{~g} / 100 \mathrm{~g})$ in the formulated complementary diet were also significantly higher $(\mathrm{p}<0.05)$ than their corresponding values of fibre $(2.0 \mathrm{~g} / 100 \mathrm{~g})$, fat $(10.0 \mathrm{~g} / 100 \mathrm{~g})$ and moisture $(3.25 \mathrm{~g} / 100 \mathrm{~g})$ in the commercial weaning diet. However, the energy value of the formulated complementary diet $(416.7 \mathrm{kcal} / 100 \mathrm{~g})$ is comparable to that of the commercial weaning diet $(410.0 \mathrm{kcal} / 100 \mathrm{~g})$.

\section{Mineral composition of the formulated complementary diet}

The results of mineral analyses of the formulated complementary diet and the control (commercial weaning diet) are presented in Table 2. It can be observed from the table that the concentration of zinc $(31.0 \mathrm{mg} / 100 \mathrm{~g})$, iron $(8.01 \mathrm{mg} / 100 \mathrm{~g})$ and magnesium $(65.17 \mathrm{mg} / 100 \mathrm{~g})$ in the formulated complementary diet were significantly higher $(\mathrm{p}<0.05)$ than their corresponding values of zinc $(5.0 \mathrm{mg} / 100 \mathrm{~g})$, iron $(7.5 \mathrm{mg} / 100 \mathrm{~g})$ and magnesium (61.08) in the commercial weaning diet, while the concentrations of calcium, potassium, sodium, manganese, 
copper and phosphorus in the formulated complementary diet were significantly lower $(\mathrm{p}<0.05)$ than their corresponding values in the commercial weaning diet.

\section{Amino acid composition of the formulated complementary diet}

The results of amino acid composition of the formulated complementary diet and the FAO reference values are presented in Table 3. The levels of the essential amino acids, Leucine, Phenylalanine and Threonine in the formulated complementary diet were significantly higher $(\mathrm{p}<0.05)$ when compared to FAO reference values while the concentration of the remaining amino acids was comparable with the FAO reference values. This suggests that most of the essential amino acids in the formulated complementary diet met the FAO reference values.

\section{Antinutritional factors in the formulated complementary diet}

The results of antinutritional factors in the formulated complementary food are as presented in Table 4 . The results showed low concentrations for all the tested antinutritional factors.

Table 1: Proximate and Energy content of a formulated complementary diet.

\begin{tabular}{lll}
\hline Parameters & Formulated diet & $\begin{array}{l}\text { Commercial weaning diet* } \\
\text { (control) }\end{array}$ \\
\hline Crude Protein $(\mathrm{g} / 100 \mathrm{~g})$ & $16.29 \pm 0.22^{\mathrm{a}}$ & 15.0 (Nestle Cerelac) \\
Crude Fibre $(\mathrm{g} / 100 \mathrm{~g})$ & $2.4 \pm 0.50$ & $2.0(\mathrm{NAN})$ \\
Crude Fat $(\mathrm{g} / 100 \mathrm{~g})$ & $11.30 \pm 0.02^{\mathrm{a}}$ & 10.0 (Nestle Cerelac) \\
Carbohydrate $(\mathrm{g} / 100 \mathrm{~g})$ & $62.46 \pm 0.50^{\mathrm{a}}$ & $65.0($ Nestle Cerelac) \\
Moisture $(\mathrm{g} / 100 \mathrm{~g})$ & $5.75 \pm 0.30^{\mathrm{a}}$ & $3.25(\mathrm{NAN})$ \\
Ash (Minerals) $(\mathrm{g} / 100 \mathrm{~g})$ & $1.80 \pm 0.22^{\mathrm{a}}$ & 3.25 (NAN) \\
Energy $($ Kcal/100g) & $416.7 \pm 0.81$ & 410 (Nestle Cerelac) \\
Calcium $(\mathrm{g} / 100 \mathrm{~g})$ & $0.20 \pm 0.61^{\mathrm{a}}$ & 0.53 (NAN) \\
Phosphorus $(\mathrm{g} / 100 \mathrm{~g})$ & $0.07 \pm 0.45^{\mathrm{a}}$ & 0.41 (Nestle Cerelac) \\
\hline
\end{tabular}

Values are expressed as mean $\pm \mathrm{SD}, \mathrm{n}=3$ for each parameter

${ }^{a}$ values are significantly different from the control (commercial weaning diet) $(\mathrm{p}<0.05)$

*Values as indicated by the manufacturer and bracket after the values indicate the name of the commercial diet.

Table 2: Mineral composition of the formulated complementary diet.

\begin{tabular}{lcc}
\hline Parameters & Formulated diet & Commercial weaning diet, Nestle NAN) \\
\hline Sodium $(\mathrm{mg} / 100 \mathrm{~g})$ & $174.0 \pm 0.72^{\mathrm{a}}$ & 180.0 \\
Potassium $(\mathrm{mg} / 100 \mathrm{~g})$ & $81.55 \pm 0.9^{\mathrm{a}}$ & 650.0 \\
Calcium $(\mathrm{mg} / 100 \mathrm{~g})$ & $381.0 \pm 1.72^{\mathrm{a}}$ & 530.0 \\
Magnesium $(\mathrm{mg} / 100 \mathrm{~g})$ & $65.17 \pm 0.10^{\mathrm{a}}$ & 61.08 \\
Iron $(\mathrm{mg} / 100 \mathrm{~g})$ & $8.01 \pm 1.30^{\mathrm{a}}$ & 7.5 \\
Zinc $(\mathrm{mg} / 100 \mathrm{~g})$ & $31.0 \pm 0.98^{\mathrm{a}}$ & 5.0 \\
Copper $(\mathrm{mg} / 100 \mathrm{~g})$ & $0.01 \pm 0.79$ & 0.37 \\
Manganese $(\mathrm{mg} / 100 \mathrm{~g})$ & $0.03 \pm 0.01^{\mathrm{a}}$ & 0.058 \\
Phosphorus $(\mathrm{mg} / 100 \mathrm{~g})$ & $70.0 \pm 0.02^{\mathrm{a}}$ & 410.0 \\
\hline
\end{tabular}

Values are expressed as mean $\pm \mathrm{SD}, \mathrm{n}=3$ for each parameter

${ }^{a}$ values are significantly different from the control (commercial weaning diet) $(\mathrm{p}<0.05)$. 
Table 3: Amino Acid Composition of a formulated complementary diet ( $\mathrm{g} / 100 \mathrm{~g}$ protein).

\begin{tabular}{lcc}
\hline Amino acids & Formulated diet & *FAO Reference Value \\
\hline Thr & 3.05 & 2.8 \\
Val & 4.03 & 4.2 \\
Trp & 0.84 & 1.4 \\
Iso & 3.60 & 4.2 \\
Leu & 7.18 & 4.2 \\
Lys & 4.14 & 4.2 \\
Phe & 3.37 & 2.8 \\
Tyr & 2.92 & 2.8 \\
Met & 2.24 & 2.2 \\
Cys & 1.09 & 2.0 \\
His & 2.36 & \\
Arg & 5.68 & \\
Asp & 8.68 & \\
Glu & 12.72 & \\
Pro & 3.04 & \\
Gly & 3.99 & \\
Ala & 3.56 & \\
Ser & 2.70 & \\
\hline
\end{tabular}

Table 4: Antinutritional factors in the formulated complementary diet (mg/100g).

\begin{tabular}{ll}
\hline Antinutrients & Concentrations $(\mathbf{m g} / \mathbf{1 0 0 g})$ \\
\hline Tannins & 0.75 \\
Phytate & 0.23 \\
Cyanide & 0.02 \\
\hline
\end{tabular}

\section{DISCUSSION}

Children require high quality protein to prevent the occurrence of protein malnutrition that is responsible for stunted growth (Okonjibola, 2017). This study reported high concentration of crude protein in the formulated complementary diet which will be able to meet the 13 to $14 \mathrm{~g}$ RDA (Solomon, 2005; Guthrie, 1989) for infants. The crude protein content of the formulated diet in this study was 10 fold higher than the values reported by Anigo et al. (2010) for formulation from different ratios of guinea corn, soybean and groundnut. The Protein concentration can be compared favourably with the earlier reports of (Olapade and Aworh, 2012) and (Omeire, 2013) who formulated diets from acha with boiled soy and coconut and extruded acha with cowpea respectively. The crude fibre obtained in the formulated complementary diet was higher than that of commercial diet and it is in agreement with the WHO recommendations for crude fibre for infants (FAO/WHO, 1989). The moisture content of formulated diet was slightly higher than the 5\% recommended moisture content for infant food according to (FAO/WHO, 1989). The total ash is directly proportional to the mineral composition of any diet. This value of ash of the formulated 
diet was higher than the values reported by Anigo et al. (2010).

Adequate energy is required to promote linear growth and prevent energy malnutrition in infants. The energy content of the formulated diet in this study was compared favourably with that of the commercial complementary diet and also falls within the (FAO/WHO, 1989) recommended range. The formulated diet was rich in iron, magnesium and zinc. According to (FAO/WHO, 2001) minerals such as iron and zinc are low in cereals but legumes are rich source of iron and zinc. Therefore, the addition of legumes to cereals in the formulated complementary diet in this study could be responsible for higher iron and zinc content. The body requires iron for proper production of red blood cells and also on regular zinc supply as obtained in the complementary diet formulated in this study may help in reducing the prevalence of stunting as linear growth was reported to be affected by zinc supply (FAO/WHO, 2001). The concentrations of calcium, potassium and phosphorus were however low. Hence, the result of this study suggests the formulated diet need to be fortified with calcium and phosphorus as they are essential for the formation of strong bones and teeth.

Protein Energy Malnutrition (PEM) is a continuous challenge in Nigeria because of the low quality of protein as a result of deficiency in essential amino acids which is commonly found in plant-based single diets (Temple et al., 1996; Anigo et al., 2009). This study reported the presence of all the essential amino acids in the formulated diet and majority of them met the FAO reference values which suggest that the high protein concentration in the newly formulated diet is of high quality.

The antinutritional factors such as phytates, tannins and cyanides has been reported to affects the bioavailability of nutrients in foods (Mbofung et al., 1990; Urbano et al., 2000; Anigo et al., 2009). The

presence of phytates and tannins results in poor bioavailability of nutrients in most cereal-based diets. Phytates concentration in the formulated complementary diet was lower than $1 \%$ reported to interfere with the bioavailability of minerals (Erdman, 1979; Urbano et al., 2000). Concentration of tannins in the formulated complementary diet was far lower than the $20 \mathrm{mg} / 100 \mathrm{~g}$ tannins reported in complementary diet formulated by ( Plahar \& Annan, 1994; Anigo et al., 2009) which indicates less unpleasant, dry and bitter mouth feeling caused by high concentration tannins that results in poor palatability of foods (Fasuyi, 2005). The cyanide concentration of the formulated complementary diet was far lower than the permissible limit reported by FAO/WHO (Anigo et al., 2009) to cause any lethal effect.

The study successfully formulated a new low-cost complementary diet with high nutritional value from locally and readily available raw materials in the rural areas (guinea corn, tiger nut, date palm, roasted groundnut and roasted soya beans) which can compete favourably with the commercial complementary diets in Nigerian market. The high content of protein, carbohydrate, fibre, fat, energy and iron/zinc in the formulated complementary diet indicate that it can be used in nutritional intervention programmes for vulnerable children in rural communities and IDPs to eradicate the prevalence of malnutrition.

\section{Conclusion}

Nutritional adequacy of
complementary foods is essential for
prevention of malnutrition and infant and
child mortality. The high prevalence of
malnutrition and child mortality rate in
northern Nigeria is due to the combined
effects of infection and low quality nutrient
complementary diets. However, from the
results of this study, it can be concluded that
careful selection and proper combination of
locally and readily available foodstuffs can


provide a cheap and nutritionally rich complementary diet that can be compared favourably with the commercially fortified infant's food. Mothers can be advised to prepare their children weaning food by combining cereals and legumes together instead of using only one. This would help to improve child growth and reduce infant and child mortality rate due to protein-energy malnutrition and diseases that arise as a result of mineral element deficiency in the diet. This may easily be achieved since all the foodstuffs used in the formulation is cost effective and can be obtained locally in rural communities of Nigeria and other sub-Saharan Africa.

\section{COMPETING INTERESTS}

The authors declared that they have no competing interest.

\section{AUTHOR'S CONTRIBUTIONS}

This work was carried out in collaboration between all authors.

EBJ conceived the idea, designed the work and wrote the first draft of the manuscript. SMG performed the statistical analysis. RJK wrote the protocol. BJG, AAE and $\mathrm{LAB}$ managed the analyses of the study. HW and HT managed the literature searches. All authors read and approved the final manuscript.

\section{REFERENCES}

Allen SE. 1974. Chemical analysis of ecological materials. Retrieved June 15, 2018 , from https://trove.nla.gov.au/work/21304847? q\&sort=holdings+desc\&_=15290660950 $73 \&$ versionId $=45810376+210012870$

Anigo KM, Ameh DA, Ibrahim S, Danbauchi SS. 2009. Nutrient composition of commonly used8/ complementary foods in North Western Nigeria. African Journal of Biotechnology, 8(17): 42114216.

Anigo KM, Ameh DA, Ibrahim S, Danbauchi SS. 2010. Nutrient composition of complementary food gruels formulated from malted cereals, soybeans and groundnut for use in North-western Nigeria. African Journal of Food Science, $\quad$ 4(3): 65-72. http://www.acadjourn.org/ajfs

AOAC. 1990. Official Methods of Analysis Vol. 1 (15ed.). AOAC Pub: Virginia, U.S.A.

http://archive.org/details/gov.law.aoac.m ethods.1.1990

Bain LE, Awah PK, Geraldine N, Kindong NP, Sigal Y, Bernard N, Tanjeko AT. 2013. Malnutrition in Sub-Saharan Africa: burden, causes and prospects. Pan African Medical Journal, 15: 120. DOI: https://doi.org/10.11604/pamj.2013.15.1 20.2535

Daelmans R, Saadeh B. 2003. Global initiatives to improve complementary feeding. In SCN Newsletter: Meeting the challenge to improve complementary feeding. United Nations System Standing Committee on Nutrition. In SCN Newsletter, Moreira AD. (Ed). Lavenhem Press: UK; 21: 10-17. DOI: https://doi.org/10.1002/ejoc.201200111

Earp CF, Akinghala JO, Ring SH, Rooney LW. 1981. Evaluation of methods to determine tannin in sorghum with varying kernel characteristics. Cereal Chemistry, 58: 234-238.

Erdman JW. 1979. Oilseed phytates: Nutritional implications. Journal of the American Oil Chemists' Society, 56(8): 736-741.

DOI: https://doi.org/10.1007/BF02663052

Eshun G. 2013. Nutrient content and sensory acceptability of a weaning diet formulated from mixtures of soya bean, groundnut and rice. African Journal of Food Science, 5(17): 1-7. DOI: https://doi.org/10.5897/AJFS11.121

FAO/WHO/UNICEF. 1971. Protein-rich mixtures for complementary foods. Protein Advisory Group of the United 
Nations, PAG guidelines no. 8 (Protein Ad). FAO/WHO/UNICEF: New York.

FAO/WHO. 1989. Protein quality evaluation. Report of the Joint FAO/WHO expert consultation.

FAO/WHO. 2001. Human Vitamin and Mineral Requirements. Human Vitamin and Mineral Requirements, 303. DOI: https://doi.org/10.1016/B978-0-32306619-8.10013-1

FAO, WHO. 1998. Preparation and use of food-bases dietary guidlines. WHO Technical Report series 880, Geneva.

Fasuyi AO. 2005. Nutrient Composition and Processing Effects on Cassava Leaf (Manihot esculenta, Crantz) Antinutrients. Pakistan Journal of Nutrition, 4(1): 37-42. DOI: https://doi.org/10.3923/pjn.2005.37.42

Fernandez DR, Vanderjagt DJ, Williams M, Huang YS, Chuang LT, Millson M, Glew RH. 2002. Fatty acid, amino acid, and trace mineral analyses of five weaning foods from Jos, Nigeria. Plant Foods for Human Nutrition (Dordrecht, Netherlands), 57(3-4): 257-274.

Guthrie HA. 1989. Introductory nutrition. Times Mirror/Mosby College Pub. https://openlibrary.org/books/OL253781 8M/Introductory_nutrition

Ikediobi CO, Onyia GOC, Eluwah CE. 1980. A Rapid and Inexpensive Enzymatic Assay for Total Cyanide in Cassava ( Manihot esculenta Crantz ) and Cassava Products. Agricultural and Biological Chemistry, 44(12): 2803-2809. DOI: https://doi.org/10.1080/00021369.1980.1 0864407

Ikujenlola AV. 2014. Chemical and functional properties of complementary food blends from malted and unmalted acha (Digitaris exilis), soybean (Glycine max) and defatted sesame (Sesamun indicum L) flours. African Journal of Food Science, $\quad \mathbf{8}(7)$ : $\quad 361-367$. DOI:10.5897/AJFS2014.1173

Mbofung CMG, Ndjourenkeu R, Nganou RK.
1990. Chemical and nutritional profile of eleven sorghum cultivars grown in the northern part of Cameroon. In: Proceedings of the Cameroon Bioscience Society.

Mehas KY, Rodgers SL. 1997. Food Science: The Biochemistry of Food and Nutrition (3Ed). Print and Technology Handbook. https://www.amazon.com/Food-ScienceBiochemistry-NutritionTechnology/dp/0026476525

Okonjibola ET. 2017. Synthesis of high quality complementary food from locally available crops. Global Journal of Food Science and Technology, 5(3): 251-257.

Olapade AA, Aworh OC. 2012. Evaluation of extruded snacks from blends of acha (Digitariaexilis) and cowpea (Vigna unguiculata) flours. Agric. Eng. Int. CIGR Journal, 14(3): 210-2017.

Omeire G. 2013. Physico-chemical Properties of Composite Flours from blends of Acha (Digiteria exile), Soyabean (Glycine max) and Coconut (Cocos mucifera) and their Use as Breakfast Meal . International Journal of Basic and Applied Sciences, 2(3): 112-117.

Onyeike EN, Olungwe T, Uwakwe AA. 1995. Effect of heat treatment and defatting on the proximate composition of some Nigerian local soup thickeners. Food Chemistry, 53(3-4):173-175. DOI: https://doi.org/10.1023/A:102183351623 4

Plahar WA, Annan N. 1994. Development of balanced protein-energy weaning foods based on local legumes and cereals. Report submitted to the Association of African Universities by Food Research Institute, Accra, Ghana.

Soekarjo D, Zehner E. 2011. Legislation should support optimal breastfeeding practices and access to low-cost, highquality complementary foods: Indonesia provides a case study. Maternal and Child Nutrition, 7(3): 112-122. DOI: https://doi.org/10.1111/j.1740- 
8709.2011.00354.x

Solomon M. 2005. Nutritive value of three potential complementary foods based on cereals and legumes. African Journal of Food, Agriculture, Nutrition and Development, 5(2): 1-14.

Spackman DH, Stein WH, Moore S. 1958. Automatic Recording Apparatus for Use in Chromatography of Amino Acids. Analytical Chemistry, 30(7): 1190-1206. DOI:

https://doi.org/10.1021/ac60139a006

Temple VJ, Badamosi EJ, Ladeji O, Solomon M. 1996. Proximate chemical composition of three locally formulated complementary foods. West African Journal of Biological Science, 5: 134143.

UNICEF. 2007. The state of the world's children 2007 women and children. UNICEF, New York, USA.

Urbano G, López-Jurado M, Aranda P, VidalValverde C, Tenorio E, Porres J. 2000.
The role of phytic acid in legumes: antinutrient or beneficial function? $J$. Physiol. Biochem., 56(3): 283-294.

Victora CG, de Onis M, Hallal PC, Blossner M, Shrimpton R. 2010. Worldwide Timing of Growth Faltering: Revisiting Implications for Interventions. Pediatrics, 125(3): e473-e480. DOI: https://doi.org/10.1542/peds.2009-1519

WFP (World Food Programme). 2005. A Manual: Measuring and Interpreting Malnutrition and Mortality. CDC and WFP.

Wheeler EL, Ferrel R. 1971. A method for Phytic Acid Determination in Wheat and Wheat fraction. Cereal Chemistry, 48: 312-320.

WHO-UNICEF. 2003. Global strategy for infant and young child feeding. WHOUNICEF, Geneva. http://www.who.int/nutrition/publication s/infantfeeding/9241562218/en/index.ht $\mathrm{ml}$. 